\title{
Prevalence of diarrheagenic Escherichia coli in children with diarrhea in Salvador, Bahia, Brazil
}

\author{
Marcia Regina Franzolin/ ${ }^{+}$, Rosely Cabette Barbosa Alves, Rogéria Keller, \\ Tânia Aparecida Tardelli Gomes*, Lothar Beutin**, Mauricio Lima Barreto***, \\ Craig Milroy***, Agostino Strina***, Hugo Ribeiro****, Luiz Rachid Trabulsi
}

\author{
Laboratório Especial de Microbiologia, Instituto Butantan, Av. Vital Brazil 1500, 05503-900 São Paulo, SP, Brasil \\ *Departamento de Microbiologia, Imunologia e Parasitologia, Universidade Federal de São Paulo, São Paulo, SP, Brasil \\ **Division of Emerging Bacterial Pathogens, Robert Koch Institut, Germany ***Instituto de Saúde Coletiva \\ ****Departamento de Pediatria, UFBa, Salvador, BA, Brasil
}

We report the frequency of the different diarrheagenic Escherichia coli (DEC) categories isolated from children with acute endemic diarrhea in Salvador, Bahia. The E. coli isolates were investigated by colony blot hibridization whit the following genes probes: eae, EAF, bfpA, Stx1, Stx2, ST-Ih, ST-Ip, LT-I, LT-II, INV, and EAEC, as virulence markers to distinguish typical and atypical EPEC, EHEC/STEC, ETEC, EIEC, and EAEC. Seven of the eight categories of DEC were detected. The most frequently isolated was atypical EPEC (10.1\%) followed by ETEC (7.5\%), and EAEC (4.2\%). EHEC, STEC, EIEC, and typical EPEC were each detected once. The strains of ETEC, EAEC, and atypical EPEC belonged to a wide variety of serotypes. The serotypes of the others categories were O26:H11 (EHEC), O21:H21 (STEC), O142:H34 (typical EPEC), and O?H55 (EIEC). We also present the clinical manifestations and other pathogenic species observed in children with DEC. This is the first report of EHEC and STEC in Salvador, and one of the first in Brazil.

Key words: typical and atypical enteropathogenic Escherichia coli (EPEC) - Shiga toxin producing E. coli (STEC) - diarrhea virulence factors

Diarrheagenic Escherichia coli (DEC) is an important cause of endemic and epidemic diarrhea worldwide (Nataro \& Kaper 1998). Currently these organisms are classified in six categories, but for practical purposes, we have divided them in eight categories: typical enteropathogenic E. coli-(t-EPEC), atypical enteropathogenic E. coli- (aEPEC), enterotoxigenic E. coli- (ETEC), enteroinvasive E. coli - (EIEC), diffusely adhering E. coli - (DAEC), enteroaggregative $E$. coli-(EAEC), enterohemorrhagic E. coli-(EHEC), and Shiga-toxin producing E. coli(STEC) (Nataro \& Kaper 1998). Table I shows the laboratory characteristics that define the DEC categories.

The aim of this study was to evaluate the contribution of the different DEC categories (and subcategories) to children's diarrhea in poor neighborhoods of Salvador, Bahia (Northeast Brazil).

\section{MATERIALS AND METHODS}

Study population - As part of an ongoing study to evaluate the health impacts of recently implemented basic sanitation (Bahia Azul Program), a sample of 1233 preschool children from diverse areas of Salvador (Teixeira et al. 2002) were monitored for 66 weeks (October 30, 2000 to January 31,2002$)$. The overall study has been described

Financial support: Pronex (contract 661086/1998-4), Department of Infrastructure of the State Government of Bahia

${ }^{+}$Corresponding author. E-mail: mrfranzolin@butantan.gov.br. Received 24 January 2005

Accepted 5 May 2005 elsewhere (Barreto, unpublished observations, Strina et al. 2003). In summary, children were visited twice weekly (72 to $96 \mathrm{~h}$ apart) and caretakers were questioned about the occurrence of diarrhea and other symptoms (number and consistency of stools, fever, vomiting, and blood in stool) since the preceding home visit. Any day in which the caretaker reported diarrhea and/or loose/liquid stools was classified as a "day with diarrhea". All "days with diarrhea" that were separated by fewer than three days of "normal" stools were considered to be part of the same diarrheal episode, while all days/episodes of diarrhea separated by at least three consecutive days of "normal" stools were considered distinct.

Sample collection - Fecal samples were collected during a 6-month period (July 24, 2001 to January 31, 2002). Caretakers received stool-collection recipients (plastic collection pots, plastic sacks, and disposable diapers) for collecting their child's feces, and were instructed to do so on any day that they judged their child to have diarrhea (regardless of the number of stools passed), and request collection of material by: (1) calling collect to the study center (Monday-Thursday, Saturday and Sunday, 7 am$4 \mathrm{pm}$ ), or (2) bringing their child directly to the study center.

When requested by telephone, a technician was sent on motorcycle to the subject's house: two swabs of material were collected from the diaper/pot/sack, placed in CaryBlair transport media and taken on ice (along with any remaining fecal material) for cataloguing and sample preparation. Whenever children were brought to the study center, two rectal swabs were taken, set in transport media, and refrigerated. 
Culture - Culture for E. coli was made in MacConkey agar (Merck) and incubated overnight. Colonies were confirmed as E. coli using biochemical tests. As a rule 2-3 lactose-fermenting colonies, presumed to be $E$. coli by colony morphology were examined for DEC. Bacterial testing for Salmonella, Shigella, Yersinia, Aeromonas, and Vibrio was conducted using standard procedures (Koneman et al. 1997). Campylobacter jejuni-coli was identified through a sample-filtration technique (Steele \& McDermott 1984). Adenovirus and rotavirus (group A) were identified by enzyme immunoassay (Biomanguinhos, Oswaldo Cruz Foundation) and polyacrilamine gel electrophoresis (PAGE). Parasitological examinations for helminthes and protozoa were conducted using the KatoKatz (Katz et al. 1972) and sedimentation (Koneman et al. 1997) methods. To test for Cryptosporidia sp., stool specimens were sieved and submitted to the formol-ether concentration method (Allen \& Ridley 1970).

DEC identification - Colony hybridization using specific radiolabelled DNA probes was used to identify the following DEC virulence factors: eae (E. coli attaching and effacing gene encoding intimin), EAF (E. coli adherence factor), $b f p \mathrm{~A}$ (bundle forming pilus structural gene), daaC (accessory gene for F1845 fimbriae biogenesis), EAEC (enteroaggregative E. coli adherence plasmid), INV (E. coli invasiveness plasmid), LT-I and II (heat-labile enterotoxin type I and II), ST-Ih and ST-Ip (heat-stable enterotoxin type I of human and porcine origin respectively), Stx-1 and 2 (Shiga toxin 1 and 2 genes) (Ghilard et al. 2003).

Serotyping and PCR typing of flagellar (fliC) genes of $E$. coli - Serotyping of E. coli $\mathrm{O}$ and $\mathrm{H}$-antigens was performed as described previously (Orskov \& Orskov 1984), at the National Reference Laboratory for Escherichia coli, Germany, by L Beutin. Determination of flagellar $(f l i C)$ genotypes was performed by PCR followed by analysis of $\mathrm{HhaI}$ digested $\mathrm{fliC}$ specific PCR products as described previously (Beutin et al. 2004).

\section{RESULTS}

A total of 175 samples were considered; of these, 169 samples were tested for Salmonella, Shigella, Yersinia, Aeromonas, Vibrio, and E. coli, 124 for Campylobacter, 139 for virus, 158 for Cryptosporidia, and 164 for helminthes/other protozoa. E. coli was suspected in 138 samples (i.e. $81.7 \%$ of all samples examined for bacteria); of these, 119 were confirmed positive (86.2\%) and 30 were found to contain diarrheagenic strains (Table I) (i.e. 17.1\% of all samples received, $21.7 \%$ of all samples tested for $E$. coli, and $25.2 \%$ of all confirmed samples).

The prevalence of each category of DEC is shown in Table II. The most frequently identified DEC were a-EPEC $(10.1 \%)$, followed by ETEC (7.5\%), and EAEC ( $4.2 \%)$. Nine ETEC strains were identified: 5 reacted only with the probe for LT, 3 for ST and 1 with the probes for both enterotoxins. In addition, one of the a-EPEC strains reacted with the probe for ST. t-EPEC, STEC, EHEC, and EIEC were detected only once each and DAEC was not detected.

The DEC serotypes were attributed to 18 O-groups and 17 different H-types (Table III). Seven strains were O-
TABLE I

Phenotypic and genotypic laboratory characteristics that define the diarrheagenic Escherichia coli (DEC) categories

\begin{tabular}{|c|c|}
\hline $\begin{array}{l}\text { DEC } \\
\text { categories }\end{array}$ & Characteristics \\
\hline t-EPEC & Presence of the eae gene and the EAF plasmid \\
\hline a-EPEC & $\begin{array}{l}\text { Presence of the eae gene and absence of the stx } \\
\text { genes }\end{array}$ \\
\hline EHEC & $\begin{array}{l}\text { Presence of the eae gene and stx genes or } \\
\text { production of Stx toxins }\end{array}$ \\
\hline STEC & $\begin{array}{l}\text { Presence of the stx genes or production of Stx } \\
\text { toxins }\end{array}$ \\
\hline ETEC & $\begin{array}{l}\text { Presence of the genes for ST and/or LT or } \\
\text { production of these toxins }\end{array}$ \\
\hline EAEC & $\begin{array}{l}\text { Presence of the EAEC gene or expression of the } \\
\text { AA pattern }\end{array}$ \\
\hline DAEC & $\begin{array}{l}\text { Presence of the } d a a C \text { gene or expression of the } \\
\text { DA pattern }\end{array}$ \\
\hline EIEC & Presence of the pINV or positive Serèny test \\
\hline
\end{tabular}

TABLE II

Prevalence of the different diarrheagenic Escherichia coli (DEC) categories in 119 children with diarrhea

\begin{tabular}{lcr}
\hline DEC categories & No. patients & $\%$ \\
\hline t-EPEC $^{a}$ & 1 & 0.8 \\
a-EPEC $^{a}$ & 12 & 10.1 \\
ETEC $^{b}$ & 9 & 7.5 \\
EAEC & 5 & 4.2 \\
EHEC (Stx1 and eae) & 1 & 0.8 \\
STEC (Stx2) & 1 & 0.8 \\
EIEC & 1 & 0.8 \\
Non-diarrheagenic E. coli & 89 & 74.8 \\
\hline Total & 119 & 100.0
\end{tabular}

$\bar{a}$ : one strain had the St-Ih gene; $b$ : ST-Ih - 2; ST-Ip - 1; ST-Ip and LT-I - 1; LT-I - 5

nontypeable (Ont) and four had a rough LPS (R). Five strains were non-motile and were investigated for their fliC genotype by PCR. The EHEC strain belonged to serotype O26:H11, and the t-EPEC strain belonged to serotype O142:H34. The serotype of the EIEC strain could not be determined because it was rough. This strain was submitted to test of keratoconjuntivitis in guinea pigs (Sèreny 1955), but presented negative result. All a-EPEC and EAEC strains belonged to different serotypes.

Other enteric pathogens identified in samples containing DEC are shown in Table IV, and clinical manifestations are shown in Table V. Duration of the diarrheal episodes was similar for the more frequent DECs, and no blood was reported in the feces of the children with EHEC and with EIEC.

\section{DISCUSSION}

In this study, seven of the eight different DEC categories were detected in children with endemic diarrhea in 
TABLE III

Sorotypes of the diarrheagenic Escherichia coli (DEC) categories

\begin{tabular}{|c|c|}
\hline Categories & Serotypes (no. of strains) \\
\hline t-EPEC & O142:H34 (1) \\
\hline a-EPEC & $\begin{array}{l}\text { O25:H33 (1), O45:H8 (1), O88:H8 (1), } \\
\text { O114:H34 (1), O138:H28 (1), O140:H34 (1), } \\
\text { O145:H34 (1), O171:H19 (1), Ont:H25 (1), } \\
\text { Ont:[H32] (1), R:H2 (1), R:H33 (1), }\end{array}$ \\
\hline ETEC & $\begin{array}{l}\text { O23:H15 (1), O27:H7 (1), O64:NM (2), } \\
\text { O159:H? (1), O166:[H15] (1), Ont:H4 (1), } \\
\text { Ont:H10 (1), Ont:H16 (1), }\end{array}$ \\
\hline EAEC & $\begin{array}{l}\text { O8:H19 (1), OR:H18 (1), O128:H16 (1), } \\
\text { OR:H? (1), Ont:[H4] (1) }\end{array}$ \\
\hline EHEC & O26:H11 (1) \\
\hline STEC & $\mathrm{O} 21: \mathrm{H} 21$ (1) \\
\hline EIEC & Ont:H55 (1) \\
\hline \multicolumn{2}{|c|}{$\begin{array}{l}\text { R: O-antigen rough; Ont: O-antigen non-typeable with } \mathrm{O} 1 \text { to } \\
\text { O181 antisera; H-type in [ ] indicates non-motile strains which } \\
\text { flagellar }(f l i C \text { ) genotype was determined by PCR/RFLP typing; } \\
\text { NM non-motile strains negative for fliC genes by PCR; H? = H- } \\
\text { antigen no typeable with antisera } \mathrm{H} 1 \text { to H56. }\end{array}$} \\
\hline
\end{tabular}

TABLE IV

Parasitic species identified in the fecal samples positive for diarrheagenic Escherichia coli

\begin{tabular}{|c|c|c|}
\hline Type & No. of cases & Other parasitic species identified \\
\hline t-EPEC & 1 & \\
\hline a-EPEC & 12 & $\begin{array}{l}\text { Ascaris lumbricoides }(1), \\
\text { Astrovirus }(1), \text { Cryptosporidium } \\
\text { parvum and T. trichiura (1), } \\
\text { Rotavirus }(1), \text { A. lumbricoides, } \\
\text { Entamoeba coli, and E. nana (1), } \\
\text { Reovirus, and Entamoeba coli (1) }\end{array}$ \\
\hline ETEC & 9 & $\begin{array}{l}\text { A. lumbricoides (1), Rotavirus (1), } \\
\text { A. lumbricoides and Entamoeba } \\
\text { coli }(1), \text { C. jejuni-coli, T. trichiura, } \\
\text { and Entamoeba coli }(1), \text { Giardia } \\
\text { lamblia }(1)\end{array}$ \\
\hline EAEC & 5 & $\begin{array}{l}\text { Adenovirus, G. lambia, and } \\
\text { A. lumbricoides (1), Astrovirus (1) }\end{array}$ \\
\hline EHEC & 1 & Rotavirus and T. trichiura (1) \\
\hline EIEC & 1 & Rotavirus (1) \\
\hline STEC & 1 & Astrovirus and T. trichiura (1) \\
\hline
\end{tabular}

Others enteropathogenic bacteria were not isolated in the clinicals samples.

TABLE V

Summary of symptoms associated with diarrheagenic Escherichia coli isolates

\begin{tabular}{|c|c|c|c|c|c|c|c|}
\hline \multirow[b]{2}{*}{ E. coli type } & \multirow{2}{*}{$\begin{array}{c}\text { Total } \\
\text { isolates }\end{array}$} & \multirow{2}{*}{$\begin{array}{l}\text { Episode } \\
\text { duration }\end{array}$} & \multirow{2}{*}{$\begin{array}{l}\text { Total loose/liquid } \\
\text { bowel movements } \\
\text { (per episode) }\end{array}$} & \multicolumn{4}{|c|}{ Number of patients reporting symptoms } \\
\hline & & & & Bloody stools $(\%)$ & Fever $(\%)$ & Cough $(\%)$ & vomiting $(\%)$ \\
\hline a-EPEC & $\begin{array}{c}12 \\
(10)^{a}\end{array}$ & $\begin{array}{c}6 \text { days } \\
(5.1 \text { days })^{a}\end{array}$ & $\begin{array}{c}16.7 \\
(17.0)^{a}\end{array}$ & 0 & $\begin{array}{c}4 \\
(40)\end{array}$ & $\begin{array}{c}4 \\
(40)\end{array}$ & $\begin{array}{c}2 \\
(20)\end{array}$ \\
\hline ETEC & $\begin{array}{c}9 \\
(5)\end{array}$ & $\begin{array}{l}3.8 \text { days } \\
(2.4 \text { days })\end{array}$ & $\begin{array}{c}6.2 \\
(4.3)\end{array}$ & 0 & $\begin{array}{c}1 \\
(20)\end{array}$ & $\begin{array}{c}3 \\
(60)\end{array}$ & 0 \\
\hline EAEC & $\begin{array}{c}5 \\
(4)\end{array}$ & $\begin{array}{l}2.8 \text { days } \\
\text { (1.7 days) }\end{array}$ & $\begin{array}{l}5 \\
(3)\end{array}$ & $\begin{array}{c}1 \\
(25)\end{array}$ & $\begin{array}{c}1 \\
(25)\end{array}$ & $\begin{array}{c}2 \\
(50)\end{array}$ & $\begin{array}{c}1 \\
(25)\end{array}$ \\
\hline t-EPEC & 1 & 5 days & 6 & 0 & 0 & 1 & 1 \\
\hline EHEC & 1 & 7 days & 3 & 0 & 1 & 1 & 1 \\
\hline EIEC & 1 & 4 days & 17 & 0 & 0 & 0 & 1 \\
\hline STEC & 1 & 1 day & 5 & 0 & 1 & 1 & 0 \\
\hline $\begin{array}{l}\text { Non-diarrheagenic } \\
\text { E. coli }\end{array}$ & $\begin{array}{c}93 \\
(75)\end{array}$ & $\begin{array}{l}6 \text { days } \\
(5 \text { days })\end{array}$ & $\begin{array}{l}15.1 \\
(15.6)\end{array}$ & $\begin{array}{c}5 \\
(6.7)\end{array}$ & $\begin{array}{c}13 \\
(17.3)\end{array}$ & $\begin{array}{c}35 \\
(46.7)\end{array}$ & $\begin{array}{c}16 \\
(21.3)\end{array}$ \\
\hline
\end{tabular}

$a$ : isolate in period with follow up data

Salvador, Bahia. Atypical EPEC was the most commonly isolated category. In addition, we identified two EHEC/ STEC strains and observed a very low frequency of tEPEC. The frequency of the remaining categories was similar to that reported in previous studies (Gomes et al. 1991, Rosa et al. 1998, Regua-Mangia et al. 2004). Tornieporth et al. (1995) conducted an epidemiological study with children in Salvador, Bahia. They evaluated 76 children with diarrhea and 16 children without diarrhea, using PCR technique and identified $16 \%$ of the children with enterotoxigenic $E$. coli, $8 \%$ with enteropathogenic $E$. coli (BFP posi- tive), and $1 \%$ with enteroinvasive $E$. coli infections, but nevertheless they did not investigate the genes for others categories.

Atypical EPEC are emergent enteric pathogens that have only recently began to attract the attention of investigators (Trabulsi et al. 2002). The high frequency of these organisms in this study reinforces the need for further studies on their epidemiology, pathogenesis, and role in the different forms of diarrhea. In contrast to typical EPEC, they seem to be common in domestic animals (Trabulsi et al. 2002), have been implicated in large food poisoning 
outbreaks in adults (Viljanen et al. 1990, Hedberg et al. 1997) and are relatively unknown in regard to virulence determinants (Pelayo et al. 1999). The isolation of two EHEC/STEC strains was also interesting and a cause of concern, since this is the first time that these organisms have been registered in Salvador, and one of the first in Brazil. Although a few EHEC/STEC strains were isolated in the 80s (Giraldi et al. 1990, Gomes et al. 1996), they seem to be occurring more frequently in the last few years. In addition to the strains detected in this study, three O157:H7 strains (Irino et al. 2002) and one O26:H11 strain (strain isolated from a case of HUS - Guth et al. 2002) have been reported in São Paulo. Cantarelli et al. (2000) also reported one instance of O91:H21 in Porto Alegre. EHEC/STEC are frequently isolated from cattle in Brazil (Cerqueira et al. 1999), and we recently isolated an O157:H7 strain from a child with diarrhea in Salvador (Trabulsi, unpublished observations). Taken together, these findings suggest that EHEC/STEC infections are on the rise in Brazil and require more attention from our public health services.

The finding of only one typical EPEC strain was somewhat surprising, but appears to confirm a recent trend that has been observed in Brazil (Girão et al. 2001, Da Silva Duque et al. 2002, Rodrigues et al. 2002). Until the $90 \mathrm{~s}$, these organisms were the main cause of infantile diarrhea in Brazil (Gomes et al. 1991, Rosa et al. 1998, ReguaMangia et al. 2004), but it seems that they are becoming more and more rare. The reason for this fall in the typical EPEC frequency has not been established but it may be a consequence of recent public health measures such as more efficient control of hospital infections and implementation of regular water supply in many slums. Another factor may have been the more frequent adoption of breast feeding, which is highly protective against intestinal infections since breast milk is extremely rich in antibodies against enteric pathogens (Loureiro et al. 1998). Regarding EHEC and both EPEC categories, the present situation in Brazil is becoming similar to the one that exists in developed countries were typical EPEC are very rare and atypical EPEC and EHEC are relatively frequent. It is interesting to mention that typical EPEC were rather frequent in these countries in the past (until the 60s). As t-EPEC have as host basically humans (Nataro \& Kaper 1998) it is likely that their frequency has been more influenced by the public health measures recently adopted than the frequency of a-EPEC and EHEC which are hosted by humans and animals (Trabulsi et al. 2002).

Several studies conducted in Brazil and in other countries have shown that ETEC and EAEC are frequently detected in children with diarrhea and that EIEC are much less frequent (Gomes et al. 1991, 1996, Nataro \& Kaper 1998, Regua-Mangia et al. 2004). The results of these studies corroborates the one reported here.

Serotyping of the DEC strains revealed some interesting aspects. For example, the single t-EPEC strain belonged to serotype O142:H34. This strain is not a "traditional" EPEC serotype, but it is the most frequently isolated serotype among serogroup O142 strains in Brazil (Ghilard et al. 2003). The EHEC strain belonged to serotype O26:H11, one of the most common EHEC serotypes
(Nataro \& Kaper 1998). The single EIEC strain was motile, a rare characteristic among EIEC strains (Toledo \& Trabulsi 1983), and was Sereny negative, possibly due to lost of the INV plasmid after storage. Finally, serotyping revealed the diversity of serotypes characteristic of ETEC and EAEC (Gyles 1994).

Approximately the half of the patients infected with DEC also carried parasites or viruses (Table IV) but as some of these are not associated with acute diarrhea and no other bacterial pathogens were isolated (the feces were also plated in selective media for Shigella, Salmonella, and Vibrio). Therefore, it is probable that at least some of the clinical manifestations presented by the patients (Table $\mathrm{V})$ were to a major part due to the DEC infections. It is interesting to observe that the children carrying a-EPEC and EHEC had longer periods of diarrhea than those infected with other DEC.

Further studies are needed to investigate the ecological, socio-economical, and epidemiological basis of atypical EPEC infections as an emerging pathotype in children in Brazil.

\section{ACKNOWLEDGMENTS}

To Monica Aparecida Midolli Vieira for her technical assistance in the colony hybridization assays. L Beutin was supported by funds from the European Commission project "Attaching and Effacing E. coli infections" (reference no. QLK2CT-2000-00600).

\section{REFERENCES}

Allen AVD, Ridley DS 1970. Further observations on the formolether concentration technique for fecal parasites. J Clin Pathol 23: 545.

Beutin L, Krause G, Zimmermann S, Kaulfuss S, Gleier K 2004. Characterization of Shiga toxin-producing strains isolated from human patients in Germany over a 3-year period. $J$ Clin Microbiol 42: 1099-1108.

Cantarelli V, Nagayama K, Takahashi A, Honda T, Cauduro PF, Dias GAG, Mezzari A, Brodt T 2000. Isolation of Shiga toxin-producing Escherichia coli (STEC) serotype O91:H21 from a child with diarrhea in Porto Alegre city, RS, Brazil. Braz J Microbiol 31: 266-270.

Cerqueira AMF, Guth BEC, Joaquim RM, Andrade JRC 1999. High occurrence of Shiga toxin-producing Escherichia coli (STEC) in healthy cattle at Rio de Janeiro State, Brazil. Vet Microbiol 70: 111-121.

Da Silva Duque S, Silva RM, Sabra A, Campos LC 2002. Primary fecal culture used as template for PCR detection of diarrheagenic E. coli virulence factors. J Microbiol Methods 51: 241-246.

Ghilardi ACR, Gomes TAT, Elias WP, Trabulsi LR 2003. Virulence factors of Escherichia coli strains belonging to serogroups O127 and O142. Epidemiol Infect 131: 815-821.

Giraldi R, Guth BEC, Trabulsi LR 1990. Production of Shiga toxin among Escherichia coli strains and other bacteria isolated from diarrhea in São Paulo, Brazil. J Clin Microbiol 28: 1460-1462.

Girão DM, Girão VBC, Gomes TAT, Vieira MAM, Trabulsi LR 2001. Etiologia da diarréia infantil no Rio de Janeiro. Resumo do XXI Congresso Brasileiro de Microbiologia. 
Salvador, Brasil, p.123.

Gomes TAT, Griffin PM, Ivey C, Trabulsi LR, Ramos SRTS 1996. EPEC infections in São Paulo. Rev Microbiol 27: 2533.

Gomes TAT, Rassi V, MacDonald KL, Ramos SR, Trabulsi LR, Vieira MA 1991. Enteropathogens associated with acute diarrheal disease in urban infants in São Paulo, Brazil. $J$ Infect Dis 164: 331-337.

Guth BEC, Lopes R, Vaz TMI, Irino K 2002. First Shiga toxinproducing Escherichia coli isolate from a patient with hemolytic uremic syndrome in Brazil. Emerg Infect Dis 8: 535-536.

Gyles C 1994. Escherichia coli in Domestic Animals, CAB International, Wallinggford, UK.

Hedberg C, Savarino S, Besser J, Paulus C, Thelen V, Myers L, Cameron DN, Barrett TJ, Kaper JB, Osterholm MT 1997. An outbreak of foodborne illness caused by Escherichia coli O39:NM, an agent not fitting into the existing scheme for classifying diarrheogenic E. coli. J Infect Dis 176: 16251628.

Irino K, Vaz TMI, Kato MAMF, Naves ZVF, Lara RR, Marco MEC, Rocha MM, Moreira TP, Gomes TA, Guth BE 2002. O157:H7 Shiga toxin-producing Escherichia coli strains associated with sporadic cases of diarrhea in São Paulo, Brazil. Emerg Infect Dis 8: 446-447.

Katz N, Chaves A, Pellegrino J 1972. A simple device for quantitative stool thick-smear technique in schistosomiasis mansoni. Rev Inst Med Trop 14: 397-400.

Koneman EW, Allen SD, Janda WM, Schreckenberger PC, Winn Jr. WC 1997. Diagnostic Microbiology. Color Atlas and Textbook, 5th ed., Lippincott, Philadelphia.

Loureiro I, Frankel G, Adu-Bobie J, Dougan G, Trabulsi LR, Carneiro-Sampaio MM 1998. Human colostrum contains IgA antibodies reactive to enteropathogenic Escherichia coli virulence-associated proteins: intimin, BfpA, EspA and EspB. J Pediatric Gastroenterol Nutr 27: 166-171.

Nataro JP, Kaper JB 1998. Diarrheagenic Escherichia coli. Clin Microbiol Rev 11: 142-201.

Orskov F, Orskov I. 1984. Serotyping of Escherichia coli. In Methods in Microbiology, vol 14, Academic Press, London, p. 43-112.

Pelayo JS, Scaletsky IC, Pedroso MZ, Sperandio V, Giron JA,
Frankel G, Trabulsi LR 1999. Virulence properties of atypical EPEC strains. J Med Microbiol 48: 41-49.

Regua-Mangia AH, Gomes TAT, Vieira MAM, Andrade JRC, Irino K, Teixeira LM 2004. Frequency and characteristics of diarrhoeagenic Escherichia coli strains isolated from children with and without diarrhoea in Rio de Janeiro, Brazil. $J$ Infection 48: 161-167.

Rodrigues J, Thomazini CM, Morelli A, de Batista GCM 2002. Reduced etiological role for enteropathogenic Escherichia coli in cases of diarrhea in brazilian infants. J Clin Microbiol 42: 398-400.

Rosa AC, Mariano AT, Pereira AM, Tibana A, Gomes TAT, Andrade JR 1998. Enteropathogenicity markers in Escherichia coli isolated from infants with acute diarrhoea and healthy controls in Rio de Janeiro, Brazil. J Med Microbiol 47: 781-790.

Serèny B 1955. Experimental Shigella keratoconjunctivitis; a preliminary report. Acta Microbiol Acad Sci Hung 2: 293296.

Steele TW, McDermott SN 1984. The use of membrane filters applied directly to the surface of agar plates for the isolation of Campylobacter jejuni from feces. Pathology 16: 263265.

Strina A, Cairncross S, Barreto ML, Larrea C, Prado MS 2003. Childhood diarrhea and observed hygiene behavior in Salvador, Brazil. Am J Epidemiol 157: 1032-1038.

Teixeira MG, Barreto ML, Costa MCN, Strina A, Martins DF, Prado M 2002. Sentinel areas: a monitoring strategy in public health. Cad Saúde Pública 18: 1189-1195.

Toledo MRF, Trabulsi LR 1983. Correlation between biochemical and serological characteristics of Escherichia coli and results of the Serèny test. J Clin Microbiol 17: 419-421.

Tornieporth NG, John J, Salgado K, de Jesus P, Latham E, Melo MC, Gunzburg ST, Riley LW 1995. Differentiation of pathogenic Escherichia coli strains in Brazilian children by PCR. J Clin Microbiol 33: 1371-1374.

Trabulsi LR, Keller R, Gomes TAT 2002. Typical and atypical enteropathogenic Escherichia coli. Emerg Infect Dis 8: 508-513.

Viljanen M, Peltola T, Junnila S, Olkkonen L, Jarvinen H, Kuistila M, Huovinen P 1990. Outbreak of diarrhoea due Escherichia coli O111:B4 in schoolchildren and adults: association of Vi antigen-like reactivity. Lancet 336: 381-384. 
